J. Clin. Chem. Clin. Biochem.

Vol. 16, 1978, pp. 625-629

\title{
Combined Batchwise and Continuous Flow Mechanization of Solid-Phase Radioimmunoassays
}

\author{
By H. H. Schweer, M. Cornely and R. Friedel \\ Institut für Klinische Biochemie und Frauenklinik der Medizinischen Hochschule Hannover
}

(Received May 19, 1978)

Summary: A new modification of the "coated-tube"-technique for the radioimmunoassay of human placental lactogen is described. Polyvinylchloride capillaries are used as reaction-vessels. Most working steps of the test procedure are mechanized. The possibilities and limitations of the new technique are discussed. The reliability of the method was shown by a recovery test, dilution tests, reproducibility and a comparison of the results for 71 sera, ranging from the 6 th to the 42 nd week of pregnancy, with those obtained by a conventional assay procedure.

\section{Kombinierte batchwise und continuous flow-Mechanisierung von Festphasen-Radioimmunoassays}

Zusammenfassung: Es wird eine neue Modifikation der "coated-tube"-Technik am Beispiel der radioimmunologischen Human Placenta Lactogen-Bestimmung beschrieben. Reaktionsgefäße sind Kapillaren aus Polyvinylchlorid. Die Durchführung des Tests ist weitgehend mechanisiert. Die Arbeitstechnik wird beschrieben, Möglichkeiten und Grenzen der Technik werden diskutiert. Wiederfindung, Verdünnungsreihen, Reproduzierbarkeit, sowie ein Methodenvergleich an 71 Schwangerenseren zeigen die Zuverlässigkeit der Methode.

\section{Introduction}

Solid-phase coupled antibodies were introduced in the radioimmunological assay procedure to facilitate the separation of bound and free antigen (1). Among the great number of solid-phase techniques, adsorption or coupling of the antibody to the inner surface of reaction tubes seems to be the best way to attain a simple and fast separation without any centrifugation or filtration. The antigen-antibody-reaction is slower, however, in a solidphase-radioimmunoassay than in a liquid-phase-radioimmunoassay. This is especially true for coated-tube techniques, because for the reaction with their specific binder the antigen-molecules have to diffuse to the antibodycoated surface (2). To overcome these difficulties it is necessary to minimize the inner diameter of the reaction tubes, thereby reducing the distances for diffusion and increasing the ratio antibody-coated surface to reaction volume (3). Using conventional reaction tubes this ratio can only be increased to a certain extent, because it is nearly impossible to correctly fill reaction tubes with an inner diameter of less than $4 \mathrm{~mm}$. The only way to solve the problem and to further improve the ratio surface to volume is to use tubing rather than tubes (3).

We found tubing of polyethylene, nylon, polyvinyl chloride, or polytetrafluoroethylene with an inner diameter of $0.9 \mathrm{~mm}$ and a length of $60 \mathrm{~mm}$ to be suitable for this purpose. Radioimmunoassays for insulin, digoxin, thyroxine, triiodothyronine, human placental lactogen and human thyrotropin were developed $(3,4,5)$.

The aim of the study presented here is to demonstrate that beyond the advantages arising from the high ratio of surface to volume, new concepts for the mechanization of analytical procedures may result form the use of tubing or capillaries.

Several groups have developed systems for the partial or total mechanization or even automation of radioimmunoassay-techniques $(6,7,8,9,10)$. Most have employed strategies that were originally designed for manually operated procedures, dividing the test into three essential steps: mixing of specimens and reagents, incubation, and separation of free and bound antigen.

In our opinion these three steps should be condensed to only one, including mixing, incubation, and separation. With the aid of an instrument developed by our group (11), we are able to fulfill this demand and, furthermore, to mechanize most working steps of a capillary-radioimmunoassay. Capillaries with an inner diameter of $0.4 \mathrm{~mm}$ are used, which can no longer be handled manually, thus increasing the ratio surface to volume much more than is possible in manually performed capillary-radioimmunoassay. 
Finally our concept includes the batchwise processing of standards and specimens of one assay. Thereby we are able to solve the problems arising from the generally applied sequential processing techniques, the most common of which is the so called "first tube - last tube problem" resulting from minimal changes in assay conditions which are likely to occur for example from inactivation of antibodies or slight changes in temperature.

The concept of our procedure is as follows:

72 antibody-coated capillaries are rinsed simultaneously with a mixture of tracer-antigen and sample and immediately thereafter with buffer using a very low flow rate, after the antigen-antibody-reaction has taken place within the first part of the fluid column, the second one (buffer) performs the separation of free and bound antigen.

In the present work, the possibilities, advantages, and perspectives of the new mechanized technique are exemplified by the assay for human placental lactogen, keeping in mind that the general strategy may be transferred to the radioimmunoassay of other antigens.

We do not want to participate in the discussion about the clinical importance of determinations of human placental lactogen during pregnancy $(12,13,14,15,16$, $17,18)$; our only aim is to outline the general principles of a mechanized capillary-radioimmunoassay.

\section{Methods}

\section{Solutions}

\section{Phosphate-albumin-buffer}

Sodium-phosphate $0.04 \mathrm{~mol} / \mathrm{l}$, bovine-serum-albumin $5 \mathrm{~g} / \mathrm{l}, \mathrm{pH} 7.4$.

\section{Serum-buffer}

Human placental lactogen-free serum diluted 1:200 in phosphatealbumin-buffer.

\section{Tris-buffer}

Tris(hydroxymethyl)aminomethane $0.025 \mathrm{~mol} / 1, \mathrm{pH} 8.4$.

\section{Tracer-hormone-solution $A$}

${ }^{125} \mathrm{I}$-labelled human placental lactogen in phosphate-albuminbuffer, $4.1 \mu \mathrm{g} / \mathrm{l}$, specific activity $4.1 \mathrm{GBq} / \mathrm{mg}$ tracer-hormone (Behringwerke $A G$ ).

\section{Tracer-hormone-solution B}

${ }^{125} \mathrm{I}$-labelled human placental lactogen in serum-buffer, $4.1 \mu \mathrm{g} / \mathrm{l}$.

\section{Antiserum}

The rabbit anti-human placental lactogen-serum (Behringwerke AG) was diluted $1: 100$ in NaCl-solution $0.3 \mathrm{~mol} / \mathrm{l}$ and stored at $-20^{\circ} \mathrm{C}$.

\section{Standard}

Standard-human placental lactogen (Behringwerke AG) was diluted in phosphate-albumin-buffer to a concentration of $6528 \mu \mathrm{g} / \mathrm{l}$ and stored at $-20^{\circ} \mathrm{C}$.

\section{Capillaries (tubing):}

Polyvinyl-chloride-tubing, inner diameter $0.4 \mathrm{~mm}$, length $150 \mathrm{~mm}$. Poly te trafluoroethylene tubing, inner diameter $0.85 \mathrm{~mm}$, length $60 \mathrm{~mm}$ (B. Braun Melsungen).
Conventional radioimmunoassay for human placental lactogen

The conventional test was based on the liquid-phase technique and the mechanized process on a commercially available system $^{1}$ ). Reagents of a commercial test kit were used ${ }^{2}$ ).

Instrument for the mechanization of the capillary-radioim m un oassay (cf. l. c. (11))

The capillaries are attached to calibrated microliter-syringes via exchangeable steel needles. The barrels of 72 syringes are fixed with their flanges between two steel plates which are not moveable. The buttons of the plungers are mounted between two other steel plates which can be moved up and down driven by an electric motor, thereby filling and emptying the capillaries. The transmission allows the variation of the speed over a wide range; for the human placental lactogen-assay we work with flow-rates of 54 and $0.94 \mu \mathrm{l} / \mathrm{min}$.

A rack with a capacity of 72 tubes is placed on a manually operated lifting device. With this device it is possible to bring the bottoms of the tubes to the tips of the capiliaries.

Procedure of a batchwise con tinuous-flow capillaryradioimmunoassay for hum an placental lactogen

\section{Preparation of standards and specimens}

Dilute stock-standards to cover a range from 128 to $2 \mu \mathrm{g} / 1$ human placental lactogen using tracer-solution B.

Predilute specimens 1:4 with phosphate-albumin-buffer, and finally dilute 1:51 with the tracer-solution $\mathbf{A}$.

\section{Preparation of antiserum-dilution}

Dilute stock-standard 1:20 in tris-buffer.

\section{Antibody-coating}

Slip capillaries onto the steel-needles. Dip capillaries into tubes with antiserum dilution. To fill the capillaries move up the plungers of the syringes and incubate $30 \mathrm{~min}$. Suck up the contents of the capillaries into the syringes. For rinsing dip the free ends of the capillaries into tubes filled with tris-buffer and suck up with maximal flow-rate. The antibody-coated capillaries can be used directly in the assay or, al ternatively, may be stored up to several months (3).

Procedure of an assay in polyvinyl chloride capillaries: Dip the antibody-coated capillaries, connected to the syringes, into tubes filled with standard- and specimen-tracer-mixtures, respectively. Suck up $28 \mu$ l of mixture with a flow-rate of $0.94 \mu \mathrm{l} / \mathrm{min}$. To prevent further uptake of mix ture move the tubes down after $30 \mathrm{~min}$. For rinsing, the capillaries are dipped into tubes with tris-buffer, and $10 \mu \mathrm{l}$ of buffer are sucked up with maximal flow-rate $(\overline{5} 4 \mu \mathrm{l} / \mathrm{min})$. All assay-solutions are now in the syringes. The capillaries are removed from the syringes, placed into vials and counted. The mix tures within the syringes are discarded or may be expelled into other vials and also counted. After rinsing with a detergent, the syringes can be used for the next assay.

Calculations are performed as usual via bound and free or bound radioactivity only.

\section{Results}

Preliminary tests were undertaken to study the influence of flow-rate variations and enlargement of the sample volumes on the characteristics of the standard curves.

In these tests teflon capillaries. with an inner diameter of $0.85 \mathrm{~mm}$ and a length of $60 \mathrm{~mm}$ were used. The other procedural conditions were as described above.

\footnotetext{
1) B. Braun Melsungen

2) Amersham-Buchler Braunschweig ·
} 


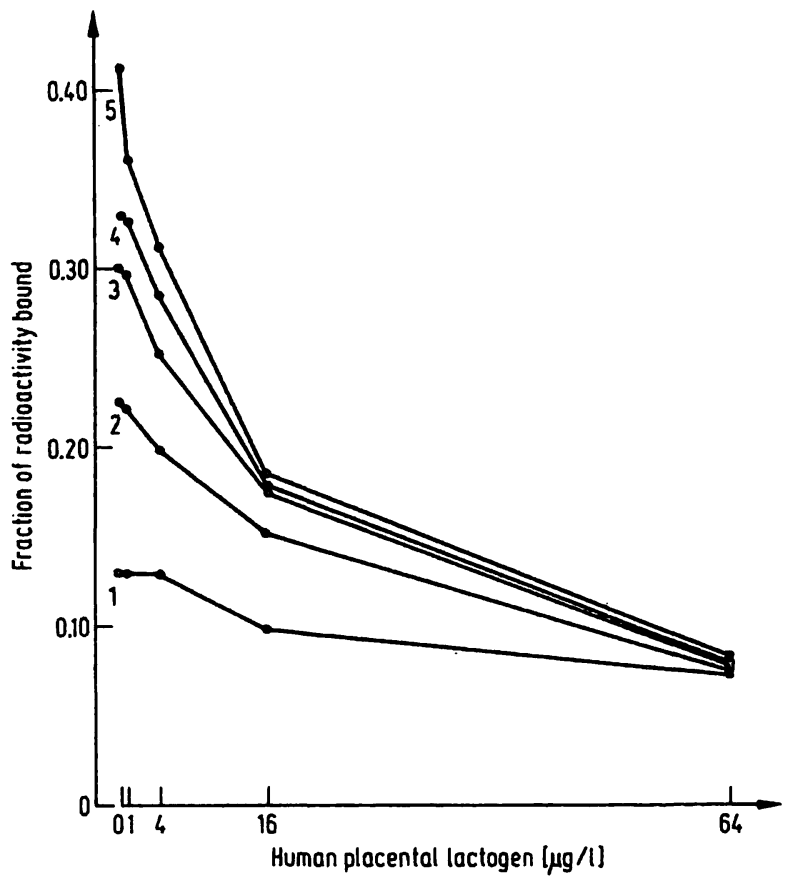

Fig. 1. Influence of flow rates on characteristics of standard curves. Test volume $50 \mu \mathrm{l}$. Poly tetrafluoroethylene capillaries $\phi=0.85 \mathrm{~mm}$, length $60 \mathrm{~mm}$.

$$
\begin{aligned}
& 1=\text { flow rate } 5 \quad \mu \mathrm{l} / \mathrm{min} \\
& 2=\text { flow rate } 1.9 \mu \mathrm{l} / \mathrm{min} \\
& 3=\text { flow rate } 1.1 \mu \mathrm{l} / \mathrm{min} \\
& 4=\text { flow rate } 0.74 \mu \mathrm{l} / \mathrm{min} \\
& 5=\text { flow rate } 0.55 \mu \mathrm{l} / \mathrm{min} .
\end{aligned}
$$

In the first experiment, the results of which are shown in figure 1 , we varied the flow rates but held the sample volumes constant at $50 \mu \mathrm{l}$ (sample volume means mixture of standard solution and tracer). Per unit of capillary surface, the incubation time varied from 10 to $91 \mathrm{~min}$. Flow-rates ranged from 0.55 to $5 \mu \mathrm{l} / \mathrm{min}$.

In the second pre-experiment mentioned here we varied sample volumes over a range of 30 to $110 \mu \mathrm{l}$, holding flow-rates constant at $0.94 \mu \mathrm{l} / \mathrm{min}$. Time of contact per unit of capillary surface ranged from 28 to $103 \mathrm{~min}$ (fig. 2).

The two experiments illustrate the concept of our technique. The sensitivity and measurement range can be influenced by altering the ratio of the length of capillary to sample volume. If minimization of the sample volume is limited, because of counting statistics, the length of the capillaries may be increased as an alternative. Variation of flow-rates with a constant sample volume results in a corresponding variation of incubation time, thereby influencing sensitivity as well as the measurement range.

\section{Performance of the radioimmunoassay for human placental lactogen in PVC-capillaries}

A 1:200 dilution of serum samples in buffer results in a measurement range of 0.5 to $14 \mathrm{mg} / \mathrm{l}$ serum. If the samples are diluted less the sensitivity can be increased

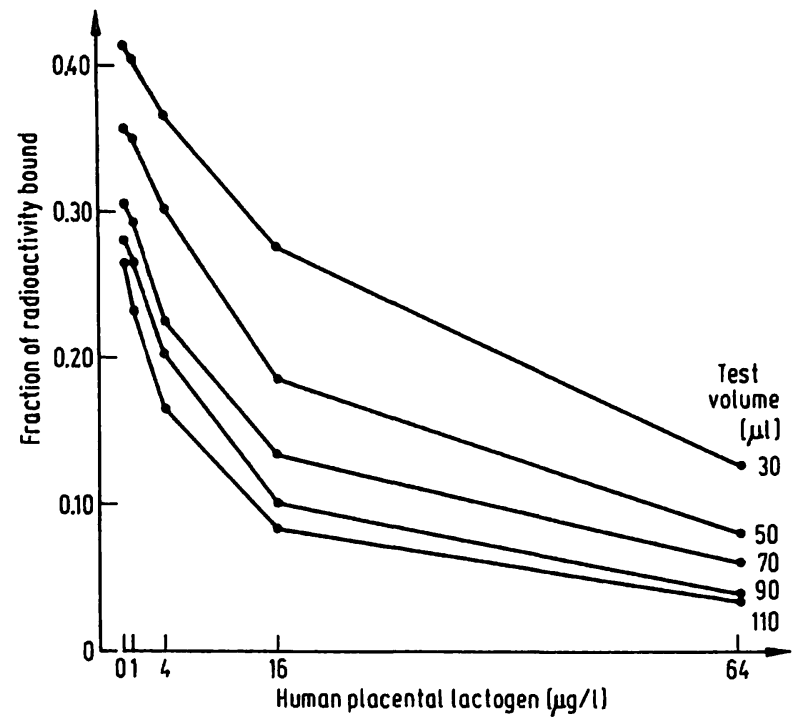

Fig. 2. Standard-curves obtained with different test volumes $(30-110 \mu \mathrm{l})$ at constant flow rates $(0.74 \mu \mathrm{l} / \mathrm{min})$. Polytetrafluoroethylene capillaries $\phi=0.85 \mathrm{~mm}$, length $60 \mathrm{~mm}$.

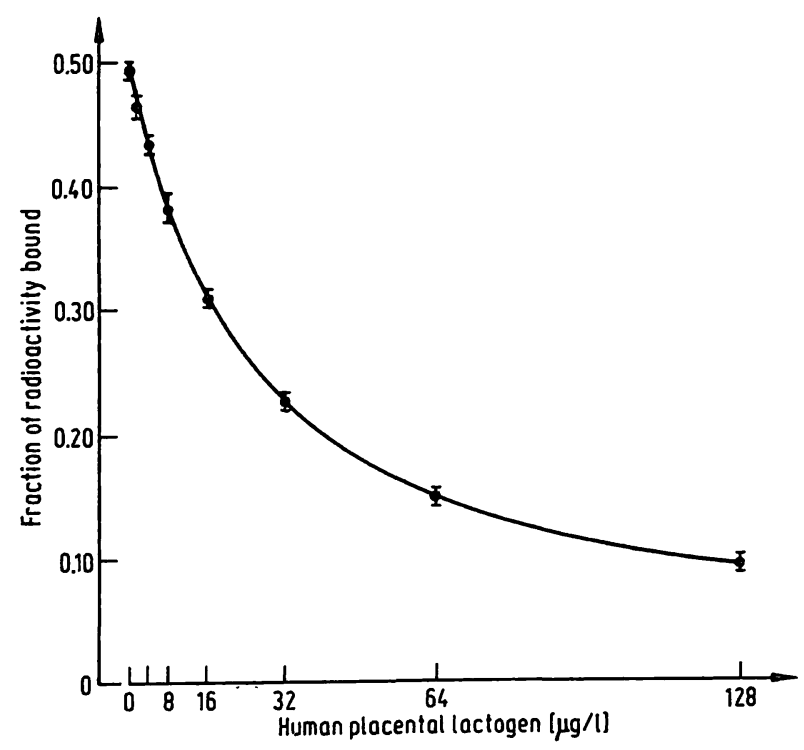

Fig. 3. Typical standard curve for the determination of human placental lactogen using coated PVC-capillaries $(\phi=0.4 \mathrm{~mm}$, length $150 \mathrm{~mm})$ and a continuous flow technique $(\bar{x} \pm S D, n=3)$. Test volume $28 \mu l$, flow rate $0.94 \mu 1 / \mathrm{min}$.

to $25 \mu \mathrm{g} / 1$. Figure 3 shows a typical standard curve. For sera diluted in the range of $1: 200$ to $1: 50$ no corrections need to be made for unspecific binding, provided the standards are adjusted to a corresponding serum dilution with a human placental lactogen-free serum. For dilutions of serum samples less than 1:50 unspecific binding has to be taken into account. The unspecific binding is determined by adding such high amounts of human placental lactogen to the sample that the concentration in the dilutions to be assayed is about $10 \mathrm{mg} / \mathrm{l}$. 
Our instrument is able to process 18 individual serum samples and 8 standard dilutions per run when sera are measured as triplicates and standards as duplicates. Also, when measuring serum samples as duplicates, 28 unknowns may be processed simultaneously in one run. Excluding counting time, one test takes about two hours, including antibody-coating.

In order to monitor the performance of our method, accuracy and reproducibility were tested. Table 1 summarizes results of recovery tests. Standard-solutions were added to five sera with different human placental lactogen concentrations. The recovery ranged from 97.6 to $111.4 \%$.

In the dilution test four different sera with high human placental lactogen concentrations were diluted stepwise from 1:100 to $1: 1600$. The dilutions were assayed in duplicate. The results are summarized in table 2 .

Precision was tested by repeated measurement of sera. For determination of within-run precision sera with human placental lactogen concentrations between 1.5 and $13.6 \mathrm{mg} / \mathrm{l}$ were processed six times in one run (dilution 1:200). The precision expressed as a coefficient of variation ranged from 3-10\%. For determination of run-to-run precision eight sera were aliquoted to portions of $100 \mu \mathrm{l}$ and stored at $-20^{\circ} \mathrm{C}$. The aliquots were processed within two months using different charges of tracer. The precision was found to be 5.6 to $13.2 \%$ expressed as a coefficient of variation. The results are summarized in table 3 .

Tab. 1. Performance of the capillary-radioimmunoassay as measured by recovery tests.

\begin{tabular}{|c|c|c|c|c|}
\hline $\begin{array}{l}\text { Basal } \\
\text { concentra- } \\
\text { tion } \\
\text { ( } \mu \mathrm{g} / \mathrm{l} \\
\text { sample } \\
\text { dilution) }\end{array}$ & $\begin{array}{l}\text { Added } \\
\text { concentra- } \\
\text { tion } \\
\text { ( } \mu \mathrm{g} / 1 \\
\text { sample } \\
\text { dilution) }\end{array}$ & $\begin{array}{l}\text { Measured } \\
\text { concentra- } \\
\text { tion } \\
(\mu \mathrm{g} / \mathrm{l} \\
\text { sample } \\
\text { dilution }\end{array}$ & $\begin{array}{l}\text { Recovered } \\
\text { concentra- } \\
\text { tion } \\
\text { ( } \mu \mathrm{g} / 1 \\
\text { sample } \\
\text { dilution) }\end{array}$ & Recovery \\
\hline $\begin{array}{r}38.5 \\
21.0 \\
9.9 \\
10.9 \\
22.4\end{array}$ & $\begin{array}{l}12.3 \\
12.3 \\
12.3 \\
12.3 \\
12.3\end{array}$ & $\begin{array}{l}50.6 \\
33.0 \\
22.1 \\
24.2 \\
36.2\end{array}$ & $\begin{array}{l}12.1 \\
12.0 \\
12.2 \\
13.3 \\
13.8\end{array}$ & $\begin{array}{r}98.8 \\
97.6 \\
99.2 \\
108.1 \\
111.4\end{array}$ \\
\hline
\end{tabular}

Tab. 2. Performance of the capillary-radioimmunoassay as measured by dilution tests.

\begin{tabular}{|c|c|c|c|c|}
\hline $\begin{array}{l}\text { Serum A } \\
\text { (mg/l } \\
\text { serum) }\end{array}$ & $\begin{array}{l}\text { Serum B } \\
\text { (mg/l } \\
\text { serum) }\end{array}$ & $\begin{array}{l}\text { Serum C } \\
(\mathrm{mg} / \mathrm{l} \\
\text { serum) }\end{array}$ & $\begin{array}{l}\text { Serum D } \\
\text { (mg/l } \\
\text { serum) }\end{array}$ & Dilution \\
\hline $\begin{array}{l}8.26 \pm 0.36 \\
8.44 \pm 0.33 \\
8.67 \pm 0.45 \\
8.10 \pm 0.70 \\
7.98 \pm 0.45\end{array}$ & $\begin{array}{l}8.08 \pm 0.41 \\
8.55 \pm 0.07 \\
8.67 \pm 0.31 \\
8.22 \pm 0.47 \\
7.02 \pm 0.59\end{array}$ & $\begin{array}{l}9.14 \pm 0.40 \\
9.39 \pm 0.26 \\
8.55 \pm 0.38 \\
8.62 \pm 0.36 \\
8.40 \pm 0.34\end{array}$ & $\begin{array}{l}7.07 \pm 0.34 \\
6.57 \pm 0.13 \\
6.71 \pm 0.24 \\
6.34 \pm 0.68 \\
5.07 \pm 0.23\end{array}$ & $\begin{array}{l}1: 100 \\
1: 200 \\
1: 400 \\
1: 800 \\
1: 1600\end{array}$ \\
\hline
\end{tabular}

Means from triplicates and standard deviations.
Tab. 3. Run-to-run precision of the capillary-radioimmunoassay determined by repeated measurement of aliquoted serum-samples within two months.

\begin{tabular}{lllllll}
\hline Serum No. & run 1 & run 2 & run 3 & run 4 & run 5 & Coeffi. \\
& (mg/1 & (mg/l & (mg/l & (mg/l & (mg/l cient of \\
& serum) & serum) & serum) & serum) & serum) & variation
\end{tabular}

\begin{tabular}{rrrrrrr}
\hline 9 & 1.48 & 1.63 & 1.84 & 1.56 & 1.32 & 12.3 \\
12 & 2.67 & 3.36 & 3.55 & 2.70 & 3.37 & 13.2 \\
18 & 2.53 & 2.91 & 2.57 & 2.79 & 2.39 & 7.9 \\
31 & 4.16 & 4.59 & 4.15 & 4.49 & 5.24 & 9.8 \\
49 & 5.33 & 5.15 & 5.04 & 4.67 & 4.73 & 5.6 \\
89 & 8.03 & 7.73 & 7.25 & 6.86 & 7.84 & 6.3 \\
111 & 4.17 & 4.35 & 4.44 & 3.87 & 4.64 & 6.8 \\
57 & 5.81 & 6.61 & 6.27 & 6.27 & 5.22 & 8.9 \\
\hline
\end{tabular}

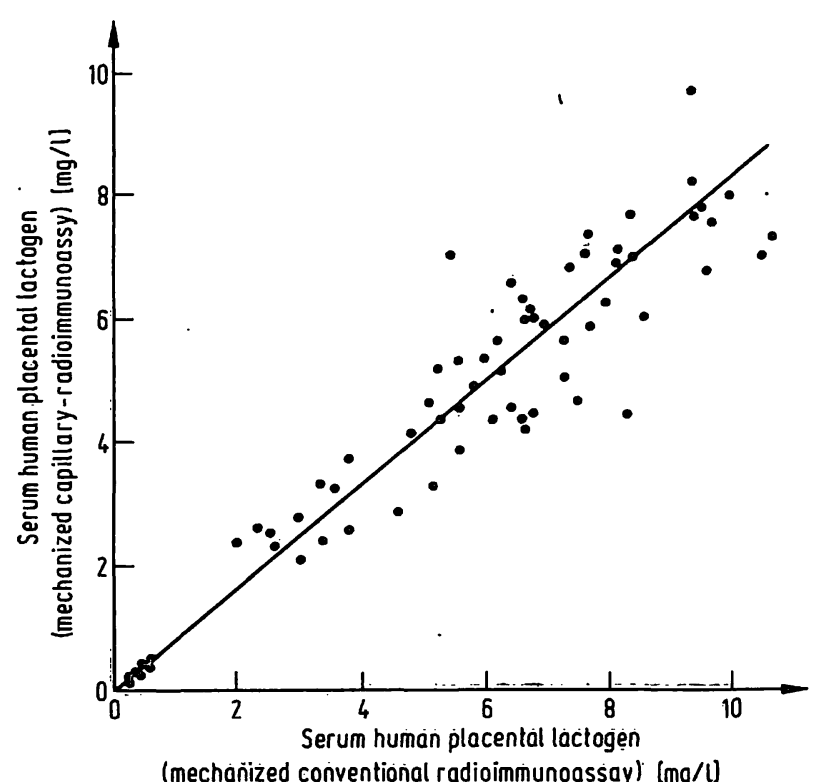

Fig. 4. Serum human placental lactogen concentrations as measured by capillary-radioimmunoassay and by a conventional radioimmunoassay. $y=0.828 x=0.007$, $r=0.942$.

In 71 sera from pregnant women (6th to 42 nd week) human placental lactogen concentrations were determined by a conventional "liquid-phase" àssay and by capillary assay (fig. 4). The least square regression analyses revealed a slope of 0.828 , a value for the intercept of -0.007 and a coefficient of correlation of 0.942 .

\section{Discussion}

Judged by common criteria of clinical chemistry, such as precision (within series and day to day) and accuracy (recovery and dilution tests), the new technique for radioimmunoassays is absolutely equivalent to conventional techniques described so far. 
In our opinion several advantages are offered by our technique compared to other radioimmunoassays:

\section{Batchwise handling of samples and standards}

In principal all comparative analytical procedures have to meet the requirement that samples and standards are handled absolutely equally. In sequential processing it is difficult to exactly fulfill these demands, because even in relatively short series differences in incubation time are likely to occur. Together with slight changes in temperature and/or partial inactivation of antibodies for example, this inevitable unequal handling leads to the so called "first tube - last tube" problem known in every laboratory. This problem can only be solved by batchwise handling of samples and standards.

\section{Reduced working time}

Because of the use of a solid-phase technique, filtration or centrifugation can be avoided. The use of capillaries overcomes the disadvantages of "coated-tubes" (unfavorable ratio surface to volume). By using extremely thin capillaries $(\phi=0.4 \mathrm{~mm})$ and by employment of the continuous flow principle, the test can be adapted to any specific requirement of the individual laboratory. Reduction of flow-rate and/or increase of sample volume makes it possible to greatly enhance sensitivity. On the other hand, the time of incubation may be decreased by acceleration of the flow-rate.

\section{References}

1. Catt, K. \& Tregear, G. W. (1967), Science 158, 1570-71.

2. Wide, L. (1977), International Symposium on Radioimmunoassay and related Procedures, Berlin, IAEA-SM-220/202, in press.

3. Friedel, R. (1976), Acta Endocrinol. Suppl. 202, 33-35.

4. Schweer, H.-H., Friedel, R. \& Trautschold, I. (1977), J. Clin. Chem. Clin. Biochem. 15, 185 (abstract).

5. Friedel, R. \& Dwenger, A. (1975), Clin. Chem. 21, 967 (abstract).

6. Dwenger, A., Friedel, R., Schweer, H.-H. \& Trautschold, I. (1976), Acta Ëndocrinol. Suppl. 202, 31-33.

7. Ertingshausen, G., Shapiro, S. I., Green, G. \& Zborowski, G. (1975), Clin. Chem. 21, 1305-13.

8. Marschner, I., Erhardt, F., Henner, J. \& Scriba, P. C. (1975), J. Clin. Chem. Clin. Biochem. 13, 481-88.

9. Friedel, R., Dwenger, A. \& Trautschold, I. (1976), G-I-T Fachz. Lab. 20, 311-14.

10. Friedel, R. (1977), Dt. Ges. F. Klin. Chemie - Mitt. 8, $1-4$.

\section{Standardisation of assay-procedures}

The solid-phase capillary-technique offers further advantages for standardisation of radioimmunoassays. The possibility of lengthening the capillaries, thereby increasing the antibody-portion per sample volume, changes a "limited-antibody system" into a "excessantibody system".

The "limited-antibody system" of classical radioimmunoassay is particularly vulnerable to environmental influences, which alter the equilibrium constant of the basic antigen-antibody-reaction. "Reagent-excess" radioimmunoassays in contrast are relatively stable against unspecific influences, because the antigen is extracted from the sample by an excess of antibody. Therefore minimal changes in equilibrium constant have little effect on the assay system (19).

Lastly, in solid-phase radioimmunoassays employing capillaries, even older charges of tracer-antigen with relatively high portions of free ${ }^{125}$ iodine can be used, if only the bound radioactivity is measured; this is because only intact tracer molecules become bound to the antibody surface. Consequently unspecific binding continues to be low.

The system described in this study is not commercially available so far, but because of its rather simple mechanical construction, it can easily be built in a short time and with low costs by any skilled technician.

11. Schweer, H.-H., Friedel, R. \& Trautschold, I. (1976), Z. Anal. Chem. 279, 111-12.

12. Altmann, P., Kucera, H. \& Spona, J. (1975), Z. Geburth. Perinat. 179, 278-85.

13. Edwards, R. P., Diver, M. J., Davis, J. C. \& Hiplin, L. J. (1976), Br. J. Obstet. Gynecol. 83, 229-37.

14. Harrigan, J. T., Langer, A., Hung, C. T., Pelosi, M. A. \& Washington, E. (1976), Obstet. Gynecol. 47, 443-45.

15. Kunz, J. \& Keller, P. J. (1976), Br. J. Obstet. Gynecol. 83, 640-44.

16. Letchword, A. T. \& Chard, T. (1972), Lancet $I, 704-706$.

17. Samaan, N. A., Smith, J. P., Rutledge, F. N. \& Schultz, P. N. (1976), Am. J. Obstet. Gynecol. 126, 186-89.

18. Spellacy, W. N., Buhi, W. C. \& Birt, S. A. (1976), Obstet. Gynecol. 47, 446-48.

19. Ekins, R. P. (1977), International Symposium on Radioimmunoassay and related Procedures, Berlin, IAEA-SM$220 / 204$, in press.

Dipl.-Chem. Hanns-Heinrich Schweer Institut für Klinische Biochemie Medizinische Hochschule Hannover Karl-Wiechert-Allee 9

3000 Hannover 61 
